\title{
Public Knowledge and Opinion on Childhood Routine Immunizations in Two Major Cities of Anambra State, Nigeria
}

This article was published in the following Dove Press journal: Journal of Multidisciplinary Healthcare

\author{
Angus Nnamdi Oli $\mathbb{D}^{\prime}$ \\ Uchenna Chukwunonso \\ Ogwaluonye' \\ Chinyere Ukamaka \\ Onubogu (iD) ${ }^{2}$
}

Abraham Faith Ozumba'

Obinna Henry Agbaenyi'

Kenneth Nchekwube Okeke ${ }^{2}$

Stanley Kenechukwu Onah $\mathbb{D}^{2}$

Jude C Okoro ${ }^{3}$

Christian Chukwuemeka

Ifezulike ${ }^{4}$

George O Emechebe (D) $^{4}$

'Department of Pharmaceutical Microbiology and Biotechnology, Faculty of Pharmaceutical Sciences, Nnamdi Azikiwe University, Agulu, Anambra State, Nigeria; ${ }^{2}$ Department of Paediatrics, Faculty of Medicine, Nnamdi Azikiwe University, Nnewi Campus, Nnewi, Anambra State, 435I0I, Nigeria; ${ }^{3}$ Department of Paediatrics, Imo State University Teaching Hospital, Orlu, Imo State, 47327I, Nigeria; ${ }^{4}$ Department of Pediatrics, Faculty of Clinical Medicine, Chukwuemeka Odumegwu Ojukwu University, Awka Campus, Awka, Anambra State, 420108, Nigeria
Background: Immunization programs suffer recurrent setbacks in developing countries.

Purpose: We evaluated the knowledge and opinion of parents towards childhood immunization.

Materials and Methods: A cross-sectional study was conducted among 2400 parents/ guardians in two major Anambra cities.

Results: The male:female ratio was $1: 1$ and about two-third (64.3\%) of respondents were aged 21-40 years. The majority were married (85.0\%), Christians $(88.3 \%)$, and had heard about childhood immunization (92.3\%) mainly from formal settings $(56.5 \%)$. A little above half $(56.2 \%)$ of them correctly cited "disease prevention" as reason for childhood immunization. A larger proportion of those that gave this correct response worked in tertiary institutions and had post-secondary school education $(p<0.001)$. The majority of the respondents appropriately agreed or disagreed with opinions that can influence immunization uptake. However, some of them did not agree that immunization was important during the first year of life $(16.7 \%)$ or afterwards $(23.1 \%)$; to ensure full immunization $(22.8 \%)$ or maintain proper immunization records $(25.6 \%)$ of their children; and to actively support childhood immunization (33.9\%). Likewise, some respondents would withhold immunization for perceived fear of adverse reactions (30.7\%) or if naturally acquired infection was perceived to confer better protection (28.2\%). Respondents who worked in tertiary institutions, and had higher education or family income were more likely to agree or disagree appropriately to opinions. Males had comparable opinions with females although females seemed to do better in opinions that reflect actual vaccination practice.

Conclusion: Awareness of the term "immunization" was high although knowledge of its indication did not measure up with this awareness, especially among the less educated. Most parents, especially those who worked in tertiary institutions, r had higher income, or education, were favorably disposed towards opinions that could positively influence immunization uptake. Efforts should be intensified at improving awareness on the indication, benefits and safety of immunization, and improving public opinions in order to optimize childhood immunization.

Keywords: children, vaccination, parents, acceptability, Southeast Nigeria

\section{Introduction}

Vaccination remains the bedrock of preventive health care in children. ${ }^{1}$ Vaccination against a particular disease does not only reduce the incidence, but the psychosocial and economic burden of the disease as well. Vaccination has the potential to prevent a significant proportion of deaths from major killers of under fives, such as pneumonia
Correspondence: Chinyere Ukamaka Onubogu

Department of Paediatrics, Faculty of

Medicine, Nnamdi Azikiwe University,

Nnewi Campus, Nnewi, Anambra State,

435101, Nigeria

Tel +2348037I65759

Email cu.onubogu@unizik.edu.ng
Journal of Multidisciplinary Healthcare 2021:14 247-257

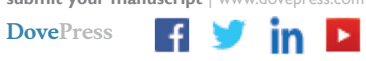

(c) (1) (5) 2021 0li et al. This work is published and licensed by Dove Medical Press Limited. The full terms of this license are available at https://www.dovepress.com/terms.php c. you hereby accept the Terms. Non-commercial uses of the work are permitted without any further permission from Dove Medical Press Limited, provided the work is properly attributed. For permission for commercial use of this work, please see paragraphs 4.2 and 5 of our Terms (https://www.dovepress.com/terms.php). 
(59\%) and diarrhea (29\%). Hence vaccination is one of the greatest success stories of public health, saving millions of children annually from deaths attributable to vaccine preventable diseases (VPDs). ${ }^{2-5}$ Through concerted efforts by governments and stakeholders, $30 \%$ increase in vaccine coverage was achieved between 2000 and 2018. ${ }^{3}$ The gains of routine childhood vaccination are evident in Nigeria and other low or middle income countries. ${ }^{6-9}$ According to the World Health Organization, all children should be fully vaccinated before their first birthday. ${ }^{10-13}$

Despite reported successes, the full benefits of vaccines are yet to be realized. In 2018, the coverage of the third dose of DPT (the vaccine against diphtheria, polio and pertussis), which is often used to measure vaccine coverage, was $86 \%$ leaving 19.4 million infants vulnerable to VPDs globally. ${ }^{3}$ Out of this, 13.5 million did not receive any vaccine dose while 5.9 million were partially vaccinated. Hence VPDs persist as an important global health challenge especially in developing countries like Nigeria. ${ }^{4,5}$

Vaccine coverage remains unsatisfactory in Nigeria, despite efforts by government and stakeholders to ensure its optimization. ${ }^{14-17}$ Nigeria currently leads the ten countries with most unprotected children globally and solely accounted for three million (15.5\%) out of the 19.4 million unvaccinated infants in 2018. ${ }^{3}$ The Northern Nigeria currently has one of the lowest immunization coverage rates in the world. ${ }^{6}$ Factors previously documented to be responsible for this include misconceptions about routine vaccination, religious influence especially among Muslims, political issues resulting in vaccine boycott, displacement of families from homes during armed conflicts or natural disasters, sporadic vaccine rejections due to mistrust and confusion, and health system related factors including inadequate cold chain, vaccine supply, training and manpower. ${ }^{18}$

Most of the above challenges are believed to be lower in southeastern Nigeria compared to other geo-political zones. ${ }^{19-21}$ Yet, despite its status as the zone with the highest vaccine coverage, only $57 \%$ and $42 \%$ of children aged 12 to 23 months in the zone received all basic and age appropriate vaccines, respectively, in 2018. ${ }^{15}$ Factors responsible for nonoptimal vaccine coverage rate in the zone are not well understood. Therefore, this study was conducted to evaluate the opinion of parents and caregivers about routine infant vaccination in two major cities (Awka and Onitsha) in Anambra state, southeastern Nigeria.
The studied population are believed to play a key role in vaccine uptake as children are completely dependent on them for access to lifesaving vaccines. It is hoped that findings will guide major key players in adopting strategies which will ensure optimal vaccine coverage and attainment of the 2030 Immunization Agenda to make vaccination available to every child, everywhere. ${ }^{2}$

\section{Materials and Methods Design}

A cross-sectional questionnaire-based study was conducted to determine the opinion of parents and caregivers on routine infant vaccination in two major cities in Anambra state, Southeast Nigeria.

\section{Study Area}

Anambra is one of the five southeastern Nigerian states with a population of more than four million $(4,182,032$ out of which $50.84 \%$ are women). ${ }^{22}$ The state is the eighth most populous, and the second most densely populated state in Nigeria with almost 700 people per square kilometer. Over $60 \%$ of the population in Anambra State live in urban areas. Anambra has three major cities: Awka (the state capital), Nnewi, and Onitsha.

According to the 2018 National Demographic Health Survey (NDHS), $87.5 \%$ of children aged 12 to 23 months received their third DPT-HepB-Hib while $75.8 \%$ and $60.4 \%$ received all basic and age appropriate vaccines, respectively, in Anambra State. ${ }^{16}$

\section{Study Population}

Participants were drawn from single or married men and women who were resident in Awka or Onitsha. Eligibility criteria were being a parent or guardian of at least one child below the age of five years, and consent to participate in the study. These were individuals who had reached the age of consent (18 years). However, two mothers less than 18 years were included because they were married, lived independent from their own parents, and were considered emancipated and eligible to give consent according to recommendations guiding adolescents' eligibility to give consent for research in Nigeria. ${ }^{23,24}$ In each town study participants were drawn from four groups comprising employees of tertiary hospitals or institutions, state or federal public service, organized private sector, and general population. 


\section{Sample Size Calculation}

The power and sample size were calculated using G-Power software version 3.1.9.2. ${ }^{25}$ A sample size of 271 evaluable participants from each of the four groups to be sampled was estimated at $99 \%$ power and $\alpha$ set at 0.01 to detect differences of 0.3 (effect size) in responses (two-tailed). Assuming a $10 \%$ attrition rate after questionnaire administration, the required sample size was set at 298.1 which was rounded off to 300 respondents.

The report was created on Tuesday, March 20, 2018 at 12:30:24 using G-Power 3.1.9.2.

A total of 2400 respondents comprising 300 participants in each of the four different groups in each of two studied towns were recruited.

Six hundred participants were drawn from each of the four groups namely:

(a) Group one: employees of tertiary hospitals/ institutions

(b) Group two: civil and public servants not in group one

(c) Group three: employees of organized private sector such as banks, private schools, churches and private companies.

(d) Group four general public (persons not in groups one to three) including self-employed individuals such as traders, artisans as well as unemployed men and women.

\section{Data Collection Tool}

Data was collected using an interviewer-administered structured questionnaire which was adapted from the questionnaire used for a similar study in Iceland. ${ }^{26}$ The questionnaire was pretested among 40 participants in Awka, the capital city of Anambra State. The questionnaire included questions on relevant sociodemographic characteristics such as gender, age, marital status, religion, housing type, place of work and residence, and average household monthly income. The opinions of the participants were assessed using Likert item statements on a five-point scale of strongly disagree, disagree, neutral, agree, and strongly agree.

\section{Subject Selection/Data Collection}

The study was conducted between April 1 and October 15, 2018. Organizations that fit into the four categories were randomly selected from lists obtained from relevant state ministries such as education, health, and commerce and industry. Subjects were proportionately allocated to the organizations according to their staff strength. In each organization, subjects allocated to each department were conveniently recruited until allocated sample size was attained. For the general public, informal trade unions such as traders and artisans associations, town and religious groups were used. Interview dates were planned to coincide with their meetings. Eligible participants were privately interviewed. Any part of the questionnaire that the respondents were unwilling to answer was left blank.

Data collection was done by the investigators with the assistance of MSc degree students of the Faculty of Pharmaceutical Sciences, Nnamdi Azikiwe University. The assistants were trained on how to elicit accurate responses from the subjects. Their proficiency was tested during the pilot-testing of the questionnaire.

\section{Data Analysis}

Data were inputted into SPSS and were presented as frequency and percentages using descriptive statistics. The mean calculation for each Likert item or statement was used to derive the opinion of the population. Mean values of 3.5 to 5 were referred to as an opinion being generally accepted while from 0 to 2.49 meant that the sample disagreed. The standard deviation was used to assess the variation in opinion for each item.

Chi-squared test was used to determine the presence of an association between demographic characteristics and different public opinions. Measures of association (Cramer's V and Kendall tau-b) were used to support the chi-squared test and in addition, demonstrate the strength of the associations detected. The difference in the mean responses of males and females was examined using Student's $t$-test. Statistical significance was established at $p<0.05$.

\section{Ethical Considerations}

This study was conducted in accordance with the Declaration of Helsinki. Prior to commencement of the study, approval was obtained from the Ethics Committee of Nnamdi Azikiwe University Teaching Hospital, Nnewi (Approval Number: NAUTH/CS/66/VOL.11/027/2018/ 002 of March 23, 2018). In addition, permission was obtained from the management of study sites, relevant heads of units or departments as well as leaders of relevant associations. All participants were eligible to give an informed consent. A written informed consent was 
obtained from the participants after explanation of the purpose and nature of the study. Participation was purely voluntary. Study participants had the freedom to withdraw from participation at any time with absolutely no repercussions. They were neither paid nor required to pay for participating.

\section{Results}

The sociodemographic characteristics of the respondents are shown in Table 1. The male:female ratio was 1:1 and about two-thirds $(64.3 \%)$ of respondents were between 21 and 40 years old. The respondents were predominantly married $(85.0 \%)$ and Christians (88.3\%). About half

Table I Sociodemographic Characteristics of Study Participants

\begin{tabular}{|c|c|c|c|c|c|}
\hline Characteristics & Group One & Group Two & Group Three & Group Four & Total \\
\hline \multicolumn{6}{|l|}{ Sex } \\
\hline Male & $279(46.5)$ & $269(44.8)$ & $330(55.0)$ & 331 (55.2) & 1209 (50.4) \\
\hline Female & $321(53.5)$ & $331(55.2)$ & $270(45.0)$ & $269(44.8)$ & $1191(49.6)$ \\
\hline \multicolumn{6}{|l|}{ Age category } \\
\hline$\leq 20$ years & $31(5.2)$ & $94(15.7)$ & $100(16.7)$ & $97(16.2)$ & $322(13.4)$ \\
\hline $21-30$ years & $175(29.2)$ & $208(34.7)$ & $212(35.3)$ & $245(40.8)$ & $840(35.0)$ \\
\hline $31-40$ years & $258(43.0)$ & $199(33.2)$ & $128(21.3)$ & 118 (19.7) & $703(29.3)$ \\
\hline $4 I-50$ years & $120(20.0)$ & $81(13.5)$ & $116(19.3)$ & $98(16.3)$ & $415(17.3)$ \\
\hline $5 I-60$ years & $16(2.7)$ & $18(3.0)$ & $32(5.3)$ & $32(5.3)$ & $98(4.1)$ \\
\hline$>60$ years & $0(0.0)$ & $0(0.0)$ & $12(2.0)$ & $10(1.7)$ & $22(0.9)$ \\
\hline \multicolumn{6}{|l|}{ Educational status } \\
\hline None & II (I.8) & $10(1.7)$ & $56(9.3)$ & $45(7.5)$ & $122(5.1)$ \\
\hline Primary & $0(0.0)$ & $40(6.7)$ & $80(13.3)$ & $90(15.0)$ & $210(8.8)$ \\
\hline Secondary & $57(9.5)$ & $124(20.7)$ & $226(37.7)$ & $258(43.0)$ & $665(27.7)$ \\
\hline Tertiary & $315(52.5)$ & $272(45.3)$ & $186(31.0)$ & $163(27.2)$ & $936(39.0)$ \\
\hline Postgraduate & $217(36.2)$ & $154(25.7)$ & $52(8.7)$ & $44(7.3)$ & $467(19.5)$ \\
\hline \multicolumn{6}{|l|}{ Marital status } \\
\hline Married & $552(92.0)$ & $537(89.5)$ & $475(79.2)$ & 477 (79.5) & $204 \mid(85.0)$ \\
\hline Widowed & $0(0.0)$ & $12(2.0)$ & $54(9.0)$ & $48(8.0)$ & II 4 (4.8) \\
\hline Separated & II (I.8) & II (I.8) & $7(1.2)$ & $12(2.0)$ & $41(1.7)$ \\
\hline Single & $37(6.2)$ & $40(6.7)$ & $59(9.8)$ & $62(10.3)$ & $198(8.2)$ \\
\hline No response & $0(0.0)$ & $0(0.0)$ & $5(0.8)$ & $\mathrm{I}(0.2)$ & $6(0.2)$ \\
\hline \multicolumn{6}{|c|}{ Household monthly income (Naira) } \\
\hline$\leq 100,000$ & $164(27.3)$ & $307(5 \mathrm{I} .2)$ & $368(61.3)$ & $370(61.7)$ & $1209(50.4)$ \\
\hline $101,000-250,000$ & $294(49.0)$ & $182(30.3)$ & $85(14.2)$ & $112(18.7)$ & $673(28.0)$ \\
\hline$>250,000$ & $142(23.7)$ & $108(18.0)$ & $90(15.0)$ & $65(10.8)$ & $405(16.9)$ \\
\hline No response & $0(0.0)$ & $3(0.5)$ & $57(9.5)$ & $53(8.8)$ & $113(4.7)$ \\
\hline \multicolumn{6}{|l|}{ Housing type } \\
\hline Flat & $381(63.5)$ & $320(53.3)$ & $236(39.3)$ & $235(39.2)$ & $1172(48.8)$ \\
\hline Mini-flat & $88(14.7)$ & $161(26.8)$ & $199(33.2)$ & $197(32.8)$ & $645(26.9)$ \\
\hline Room(s) with shared toilet & II (I.8) & $65(10.8)$ & $130(2 \mid .7)$ & $125(20.8)$ & $331(13.8)$ \\
\hline Room(s) with no toilet & $0(0.0)$ & $0(0.0)$ & $4(0.7)$ & $10(1.7)$ & $14(0.6)$ \\
\hline Others & $120(20.0)$ & $54(9.0)$ & $31(5.2)$ & $33(5.5)$ & $238(9.9)$ \\
\hline \multicolumn{6}{|l|}{ Religion } \\
\hline Christianity & $573(95.5)$ & $519(86.5)$ & $515(85.8)$ & $513(85.5)$ & $2120(88.3)$ \\
\hline Muslim & $27(4.5)$ & $69(11.5)$ & $4 \mid(6.8)$ & $48(8.0)$ & $185(7.7)$ \\
\hline African traditional religion & $0(0.0)$ & $12(2.0)$ & $33(5.5)$ & $31(5.2)$ & $76(3.2)$ \\
\hline Others & $0(0.0)$ & $0(0.0)$ & $2(0.3)$ & $8(1.3)$ & $10(0.4)$ \\
\hline No response & $0(0.0)$ & $0(0.0)$ & $9(1.5)$ & $0(0.0)$ & $9(0.4)$ \\
\hline Total & $600(100.0)$ & $600(100.0)$ & $600(100.0)$ & $600(100.0)$ & $2400(100.0)$ \\
\hline
\end{tabular}


(50.4\%) of the families earned below 100,000 Naira per month while the commonest housing type was flat (48.8\%). More than half of the respondents $(58.5 \%)$ had post-secondary school education. Respondents who had post-secondary education were significantly more likely to belong to group one $(37.9 \%$ vs group two $30.4 \%$, group three $17.0 \%$, and group four $14.8 \%$; $p<0.001$ ), as well as families which earned beyond one hundred thousand Naira $(40.4 \%$ vs group two $26.9 \%$, group three $16.2 \%$, and group four $16.4 \% ; p<0.001)$. Likewise, respondents who lived in flats were significantly more likely to belong to group one $(32.5 \%$ vs group two $27.3 \%$, group three $20.1 \%$, and group four $20.1 \%$; $p<0.001)$

As shown in Table 2, 92.3\% (2215) of the respondents had ever heard of immunizations. Formal settings served as the initial source of information in more than half $(56.5 \%)$ of respondents with groups one and two having the highest proportions. Only about half of the subjects $(56.2 \%)$ correctly cited "disease prevention" as the reason for immunizing children with group one most likely to cite a correct response compared to other groups. Those who correctly cited the reason for vaccination were significantly more likely to belong to group one $(p<0.001)$ and have higher education $(p<0.001)$ as shown in Table 2 and Figure 1.

Majority of the 2400 participants agreed or strongly agreed that immunization is important during the first year of life $(83.3 \%)$, child immunization is important after the first year of life (76.9), to always ensure that their children are fully immunized $(77.2 \%)$, maintain proper record of children's immunization (74.4), actively support childhood immunization in their neighborhood (66.1) and readily seek medical attention if their child is noticed to have any vaccination reaction $(81.1 \%)$. Likewise majority disagreed or strongly disagreed to withholding immunization due to fear of adverse reaction $(69.3 \%)$ or belief that naturally acquired infections provide better protection than vaccination $(71.8 \%)$.

As shown in Table 3, the population was favorably disposed towards immunizing their child in the first year of life (I) or afterwards (II), ensuring their children were fully immunized (III), maintaining proper immunization record of children (IV), actively supporting childhood immunization in neighborhood (V), seeking medical attention when child is noticed to have vaccination reaction (VIII), and not withhold vaccination due to fear of adverse reaction (VI) or when naturally acquired infection is perceived provide better protection than vaccination (VII). The standard deviation was lowest for opinion I and highest from opinion $\mathrm{V}$.

As shown in Figure 2, respondents in group one followed by group two were more likely agree to positive opinions and disagree to negative ones. This association was statistically significant as shown in Table 4. Using the Cramer's V, all association measures were significant and ranged from weak to moderate. The highest association

Table 2 Knowledge About Childhood Immunization

\begin{tabular}{|c|c|c|c|c|c|}
\hline Characteristics & Group One & Group Two & Group Three & Group Four & Total \\
\hline \multicolumn{6}{|c|}{ Ever heard of child immunization } \\
\hline Yes & $587(97.8)$ & $584(97.3)$ & $523(87.2)$ & $521(86.8)$ & $2215(92.3)$ \\
\hline No & $\mathrm{II}(1.8)$ & $5(0.8)$ & $71(11.8)$ & $74(12.3)$ & $161(6.7)$ \\
\hline I do not know & $2(0.3)$ & II (I.8) & $6(1.0)$ & $5(0.8)$ & $24(\mathrm{I} .0)$ \\
\hline \multicolumn{6}{|l|}{ Initial information source } \\
\hline Formal settings & $467(77.8)$ & $365(60.8)$ & $263(43.8)$ & $260(43.3)$ & $1355(56.5)$ \\
\hline Media & $71(11.8)$ & $66(11.0)$ & $69(11.5)$ & $72(12.0)$ & $278(11.6)$ \\
\hline Health-care worker & $44(7.3)$ & $93(15.5)$ & $|3|(2 \mid .8)$ & $103(17.2)$ & $371(15.5)$ \\
\hline Friend & $6(1.0)$ & $68(11.3)$ & $64(10.7)$ & $81(13.5)$ & $219(9.1)$ \\
\hline Others & $0(0.0)$ & $\mathrm{I}(0.2)$ & $2(0.3)$ & $0(0.0)$ & $3(0.1)$ \\
\hline No response & $12(2.0)$ & $7(1.2)$ & 71 (1I.8) & $84(14.0)$ & $174(7.2)$ \\
\hline \multicolumn{6}{|c|}{ Why is immunization necessary } \\
\hline To protect from diseases & $526(87.7)$ & $337(56.2)$ & $230(38.3)$ & $255(42.5)$ & $1348(56.2)$ \\
\hline To fulfil parental obligation & $9(1.5)$ & $79(13.2)$ & $11(1.8)$ & $9(1.5)$ & $108(4.5)$ \\
\hline I do not know & $8(1.3)$ & $63(10.5)$ & $195(32.5)$ & $163(27.0)$ & $428(17.8)$ \\
\hline No response & $57(9.5)$ & $|2|(20.2)$ & $164(27.3)$ & $174(29.0)$ & $516(21.5)$ \\
\hline
\end{tabular}




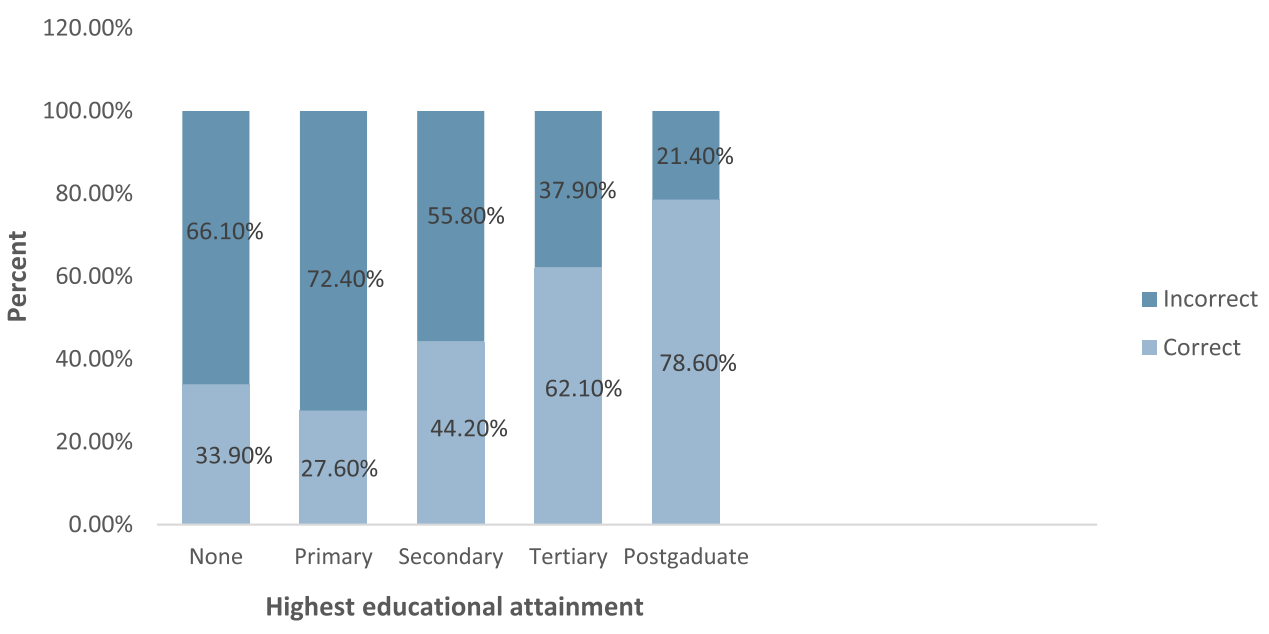

Figure I Relationship between educational status and ability to correctly cite reason for vaccination.

was 0.276 with opinion I while the lowest was 0.202 with opinion VIII.

Tables 5 and 6 were used to test and measure the association of two predictor variables (education and average family income) on the different opinions. The chisquared test for independence showed significant $p$-values $(p<0.05)$ for the associations between the predictor variables and the opinions of participants. Respondents with higher income and education were more likely to agree to positive opinions and disagree to negative opinions.

The measures of independence performed using Kendall tau-b showed a weak to moderate significant association. It also showed a positive association for opinions I-V and VIII and a negative association for opinions VI and VII. Educational status had the highest association with opinion I $(+0.384)$ and lowest association with opinion $\mathrm{V}(+0.117)$ while average family income had the highest association with opinion I $(+0.289)$ and lowest association with opinion $\mathrm{V}(+0.065)$.

As shown in Table 7, the males were significantly more likely to agree on immunization being important after first year of life. On the other hand, the females were significantly more likely to agree to always ensure that children are fully immunized, seek medical attention when a child is noticed to have vaccination reaction, and disagree to not immunizing their child if naturally acquired infection is perceived to provide better protection than vaccination.

\section{Discussion}

The assessment of knowledge and public opinion of childhood vaccination could highlight some of the challenges and gaps that need to be addressed in order to improve the coverage of immunization. This is essential because immunization has been identified as one of the most farreaching health interventions capable of playing a crucial role in achieving 14 out of the 17 sustainable development goals (SDGs). ${ }^{2,27}$

Our findings indicate that awareness of the term immunization was generally high among Anambra residents and this agreed with a previous report. ${ }^{28}$ However, knowledge of the indication for immunization did not match up with awareness of the term as only about half of respondents

Table 3 Population Opinions on Aspects of Childhood Immunizations

\begin{tabular}{|c|c|c|c|c|}
\hline $\mathbf{S} / \mathbf{N}$ & Opinion & Mean & SD & Remarks \\
\hline I & Immunization is important during the first year of life & 4.1 & 0.67 & Agreed \\
\hline II & Participating in child immunization is important after the first year of life & 4.0 & 0.75 & Agreed \\
\hline III & I always ensure that my children are fully immunized & 3.9 & 0.79 & Agreed \\
\hline IV & I maintain proper record of my children's immunization & 3.9 & 0.76 & Agreed \\
\hline V & I actively support childhood immunization in my neighborhood & 3.7 & 0.96 & Agreed \\
\hline VII & I do not immunize my children because naturally acquired infections provide better protection than vaccination & 2.2 & 0.71 & Disagreed \\
\hline VIII & I readily seek medical attention if my child is noticed to have any vaccination reaction. & 4.1 & 0.71 & Agreed \\
\hline
\end{tabular}




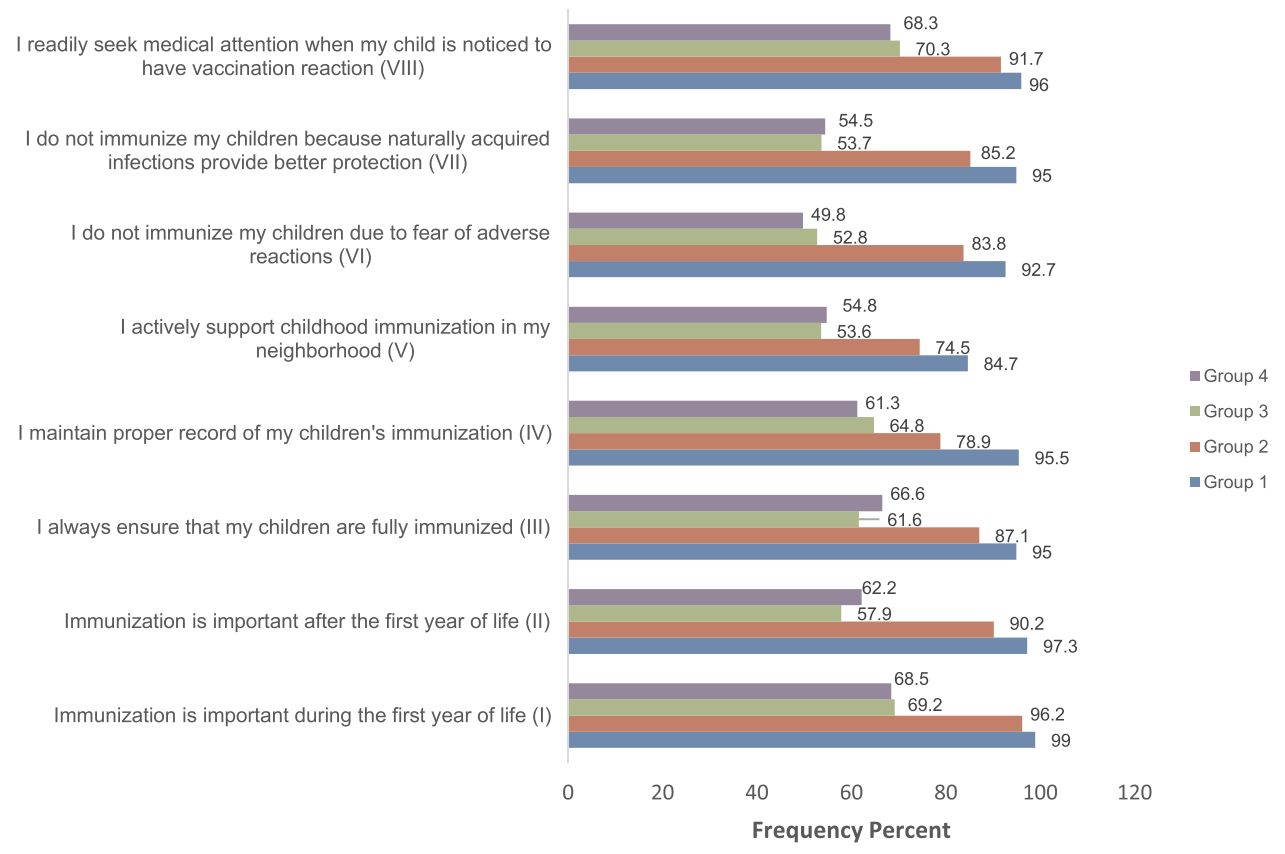

Figure 2 Agreement with positive (I, II, III, IV, V, VIII) or disagreement with negative (VI, VII) opinions among the groups.

correctly cited the reason for immunization. This corroborates previous report that parents often have wrong knowledge about vaccination. ${ }^{29}$ It is no doubt that knowledge of the benefits of immunization will improve uptake. ${ }^{6}$ Parents are more likely to pursue immunization, notwithstanding prevailing obstacles, if they are aware of its protective effects on their children. Therefore, concerted efforts should be made to ensure that parents at all levels understand the benefits of immunization.

Findings of this study agree with previous reports on the positive influence of formal education on knowledge of immunization. ${ }^{30-32}$ This was supported by the finding that the initial source of information was predominantly formal education settings. This may also be attributed to the fact that individuals who have higher education are more likely to appreciate the basic concepts of vaccination. ${ }^{31,32}$ This calls for full integration of immunization-related topics into the health education of students at all levels. Efforts should be made to improve the use of the mass media and social media channels in propagating or reinforcing messages on the benefits of childhood immunization. Healthcare professionals served as the second most common information source. Efforts at this role should be intensified to ensure that all individuals who come in contact with health-care facilities are fully aware of the benefits of childhood immunization.

The results show that parents generally agreed that childhood vaccination is relevant and were favorably

Table 4 Association Between Group/Place of Work and Opinions of Respondents

\begin{tabular}{|c|c|c|c|c|}
\hline $\mathbf{S} / \mathbf{N}$ & Opinion & Chi-squared & Cramer's V & Assessment \\
\hline I & Immunization is important during the first year of life & $548.32(p<0.001)$ & $0.276(p<0.00 I)$ & Significant Moderate association \\
\hline II & Participating in child immunization is important the first year of life & $419.58(p<0.001)$ & $0.24 I(p<0.00 I)$ & Significant Moderate association \\
\hline III & I always ensure that my children are fully immunized & $416.80(p<0.001)$ & $0.24 I(p<0.00 I)$ & Significant Moderate association \\
\hline IV & I maintain proper record of my children's immunization & $303.92(p<0.001)$ & $0.206(p<0.00 I)$ & Significant Weak association \\
\hline$\vee$ & I actively support childhood immunization in my neighborhood & $300.86(p<0.001)$ & $0.206(p<0.00 I)$ & Significant Weak association \\
\hline $\mathrm{VI}$ & I do not immunize my children due to fear of adverse reaction & $430.99(p<0.001)$ & $0.246(p<0.00 I)$ & Significant Moderate association \\
\hline VII & $\begin{array}{l}\text { I do not immunize my children because naturally acquired } \\
\text { infections provide better protection than vaccination }\end{array}$ & $443.84(p<0.001)$ & $0.249(p<0.00 \mathrm{I})$ & Significant Moderate association \\
\hline VIII & $\begin{array}{l}\text { I readily seek medical attention when my child is noticed to have } \\
\text { any vaccination reaction }\end{array}$ & $293.05(p<0.001)$ & $0.202(p<0.001)$ & Significant Weak association \\
\hline
\end{tabular}


Table 5 Association Between Educational Status and Opinions of Respondents

\begin{tabular}{|c|c|c|c|c|}
\hline $\mathbf{S} / \mathbf{N}$ & Opinion & Chi-squared & Kendall Tau-b & Assessment \\
\hline I & Immunization is important during the first year of life & $691.30(p<0.001)$ & $0.384(p<0.001)$ & Significant Moderate positive association \\
\hline II & $\begin{array}{l}\text { Participating in child immunization is important after } \\
\text { the first year of life }\end{array}$ & $524.97(p<0.001)$ & $0.249(p<0.001)$ & Significant Weak positive association \\
\hline III & I always ensure that my children are fully immunized & $558.20(p<0.001)$ & $0.224(p<0.001)$ & Significant Weak positive association \\
\hline IV & $\begin{array}{l}\text { I maintain proper record of my children's } \\
\text { immunization }\end{array}$ & $683.84(p<0.001)$ & $0.299(p<0.001)$ & Significant Moderate positive association \\
\hline $\mathrm{V}$ & $\begin{array}{l}\text { I actively support childhood immunization in my } \\
\text { neighborhood }\end{array}$ & $576.37(p<0.001)$ & $0.117(p<0.001)$ & Significant Weak positive association \\
\hline $\mathrm{VI}$ & $\begin{array}{l}\text { I do not immunize my children due to fear of adverse } \\
\text { reactions }\end{array}$ & $702.38(p<0.001)$ & $-0.295(p<0.001)$ & Significant Weak negative association \\
\hline VII & $\begin{array}{l}\text { I do not immunize my children because naturally } \\
\text { acquired infections provide better protection than } \\
\text { vaccination }\end{array}$ & $653.66(p<0.001)$ & $-0.364(p<0.001)$ & Significant Moderate negative association \\
\hline VIII & $\begin{array}{l}\text { I readily seek for medical attention when my child is } \\
\text { noticed to have any vaccination reaction }\end{array}$ & $383.92(p<0.001)$ & $0.225(p<0.001)$ & Significant Weak positive association \\
\hline
\end{tabular}

Table 6 Association Between Average Income and Opinions of Respondents

\begin{tabular}{|c|c|c|c|c|}
\hline $\mathbf{S} / \mathbf{N}$ & Opinion & Chi-squared & Kendall Tau-b & Assessment \\
\hline I & Immunization is important during the first year of life & $244.67(p<0.001)$ & $0.289(p<0.001)$ & Significant Moderate positive association \\
\hline II & $\begin{array}{l}\text { Participating in child immunization is important after } \\
\text { the first year of life }\end{array}$ & $170.67(p<0.001)$ & $0.173(p<0.001)$ & Significant Weak positive association \\
\hline III & I always ensure that my children are fully immunized & $105.92(p<0.001)$ & $0.138(p<0.001)$ & Significant Weak positive association \\
\hline IV & $\begin{array}{l}\text { I maintain proper record of my children's } \\
\text { immunization }\end{array}$ & $173.8 \mid(p<0.00 \mid)$ & $0.212(p<0.001)$ & Significant Weak positive association \\
\hline V & $\begin{array}{l}\text { I actively support childhood immunization in my } \\
\text { neighborhood }\end{array}$ & $67.82(p<0.001)$ & $0.065(p<0.001)$ & Significant Weak positive Association \\
\hline $\mathrm{VI}$ & $\begin{array}{l}\text { I do not immunize my children due to fear of adverse } \\
\text { reactions }\end{array}$ & $261.64(p<0.001)$ & $-0.186(p<0.001)$ & Significant Weak negative association \\
\hline VII & $\begin{array}{l}\text { I do not immunize my children because naturally } \\
\text { acquired infections provide better protection than } \\
\text { vaccination }\end{array}$ & $256.58(p<0.001)$ & $-0.228(p<0.001)$ & Significant Moderate negative association \\
\hline VIII & $\begin{array}{l}\text { I readily seek for medical attention when my child is } \\
\text { noticed to have any vaccination reaction }\end{array}$ & $80.74(p<0.001)$ & $0.136(p<0.001)$ & Significant Weak positive association \\
\hline
\end{tabular}

Table 7 Association Between Gender and Opinions of Respondents

\begin{tabular}{|c|c|c|c|c|}
\hline $\mathbf{S} / \mathbf{N}$ & Opinion & $\begin{array}{l}\text { Male (Mean } \\
\pm S D)\end{array}$ & $\begin{array}{l}\text { Female (Mean } \\
\pm S D)\end{array}$ & $\begin{array}{l}p- \\
\text { value }\end{array}$ \\
\hline I & Immunization is important during the first year of life & $4.1 \pm 0.63$ & $4.0 \pm 0.70$ & 0.087 \\
\hline II & Participating in child immunization is important after the first year of life & $4.0 \pm 0.77$ & $3.9 \pm 0.72$ & $0.018^{*}$ \\
\hline III & I always ensure that my children are fully immunized & $3.9 \pm 0.78$ & $4.0 \pm 0.80$ & $0.002 *$ \\
\hline IV & I maintain proper record of my children's immunization & $3.9 \pm 0.74$ & $3.9 \pm 0.78$ & 0.957 \\
\hline V & I actively support childhood immunization in my neighborhood & $3.7 \pm 0.94$ & $3.7 \pm 0.97$ & 0.786 \\
\hline VI & I do not immunize my children due to fear of adverse reaction & $2.2 \pm 0.80$ & $2.3 \pm 0.74$ & 0.637 \\
\hline VII & $\begin{array}{l}\text { I do not immunize my children because naturally acquired infections provide better } \\
\text { protection than vaccination }\end{array}$ & $2.2 \pm 0.73$ & $2.1 \pm 0.69$ & $0.045^{*}$ \\
\hline VIII & $\begin{array}{l}\text { I readily seek for medical attention when my child is noticed to have any vaccination } \\
\text { reaction }\end{array}$ & $4.0 \pm 0.67$ & $4 . I \pm 0.73$ & $<0.001 *$ \\
\hline
\end{tabular}

Note: *Statistically significant (Student's t-test). 
disposed towards maintaining proper immunization records of their child vaccination and actively supporting childhood immunization activities. They were also favorably disposed towards disagreeing with opinions which militate against immunization uptake such as perceived fear of adverse effects that may arise from vaccine contamination/compromise, or belief that naturally acquired immunity was better. Based on these findings, it could be inferred that certain misconceptions may not have much impact on the uptake of childhood immunization in the studied population. Previously, misconception was identified as the major hindrance to childhood immunization in African settings. ${ }^{30,33,34}$ In 2003, the WHO polio vaccination campaign was boycotted by opinion leaders in three Northern Nigerian states due to misconceptions that the vaccine was contaminated with HIV and could cause sterility. ${ }^{33}$ It has also been reported that some parents prefer their children to endure the disease to being vaccinated because they believed that immunity induced by vaccines is less effective than that acquired from natural disease. ${ }^{30}$ Therefore, the trend in opinion may contribute to the higher uptake of vaccines in the southeast compared to other geopolitical zones in Nigeria. Hence, the government should intensify efforts on improving the opinion of parents towards childhood immunization in zones currently experiencing low immunization coverage especially in Northern Nigeria. Immunization programs should intensify sensitization on the safety of vaccines.

While noting that opinion trend is good, it is equally important to view the variation from the central idea. Our findings showed that active support of vaccination in the neighborhood recorded the lowest mean (3.66) and highest standard deviation (0.96). Therefore, although 83.3\% respondents agreed that vaccination is important during first year of life, only $66.1 \%$ agreed to actively support immunization activities in their neighborhood. This has serious implications for taking ownership of the immunization program to ensure optimal coverage and sustainability. In addition, although in the minority, the proportion of respondents who did not agree with positive opinions or disagree with negative ones is worrisome. The issues should be closely looked into in order to achieve optimal immunization coverage. Government and relevant stakeholders should continue to work hard to improve the opinions of the masses towards immunization.

Contrary to expectation, this study found a comparable response between males and females in half of the opinions. However, the finding that fathers are positively disposed towards immunization, is quite reassuring. This is because fathers play a key role in household decisionmaking (including decisions on preventive health care) and this may influence actual demand for immunization by the children's caretaker. ${ }^{35}$ As expected, females were significantly more likely to agree or disagree with opinions that reflected actual practice such as ensuring that children were fully immunized, seeking medical attention when child is noticed to have adverse reactions or withholding vaccination because natural infection confer stronger immunity. This may be attributed to the fact that the mothers are often the primary caretakers of children in most homes and, therefore, more likely to accompany children to health facilities for vaccination.

The predictors of public opinions were identified to include, but not limited to, average income, educational status and workplace. It is also important to note that respondents who worked in tertiary institutions were most likely to understand that immunization was important for disease prevention. This could be attributed to higher level of awareness. Therefore, efforts should be made to improve the awareness of all individuals who come in contact with hospitals on the benefits of childhood immunization. The importance of education cannot be overemphasized. $^{36}$ Therefore, governments can improve immunization uptake especially in hard-to-reach areas by improving investment in formal education.

\section{Conclusion}

Our findings indicated that the awareness of the term "immunization" was high among parents although many of them were not aware of the indication for immunization. Most parents were favorably disposed towards agreeing with opinions that positively influence immunization uptake and disagreeing with opinions that militate against immunization uptake. This was especially strong among parents who had higher education or income, or worked in tertiary institutions. The opinions of males were comparable to that of females. However, the females seemed to do better in opinions which reflect actual vaccination practice.

From our findings, it could be inferred that childhood vaccination programs will be successful in the studied cities and that vaccine rejections are less likely. However, efforts should be intensified at improving awareness on the indications, benefits and safety of immunization, and improving parents' opinions on immunization. In addition, governments should step up efforts at improving the educational and income status of parents. These are 
vital to attaining the 2030 Immunization Agenda of making all necessary vaccines available to every child, everywhere.

\section{Disclosure}

The authors report no conflicts of interest in this work.

\section{References}

1. Feikin DR, Flannery B, Hamel MJ, Stack M, Hansen PM. Vaccines for children in low- and middle- income countries. In: Black RE, Laxminarayan R, Temmerman M, Walker N, editors. Reproductive, Maternal, Newborn, and Child Health: Disease Control Priorities, Third Edition (Volume 2). Washington (DC): World Bank. 2016:187-204

2. WHO. Immunization agenda $2030 \mathrm{~A}$ global strategy to leave no one behind. Available from: https://www.who.int/immunization/IA2030_ draft_4_WHA.pdf. Accessed. July 20, 2020.

3. $\mathrm{WHO} / \mathrm{UNICEF}$. Progress and challenges with achieving universal immunization coverage: $2018 \mathrm{WHO} / \mathrm{UNICEF}$ estimates of national immunization coverage. Available from: https://www.who.int/immu nization/monitoring_surveillance/who-immuniz.pdf. Accessed May $17,2020$.

4. Institute of Medicine (US) Committee on Review of Priorities in the National Vaccine Plan. Priorities for the National Vaccine Plan. Washington (DC): National Academies Press (US); 2010. Available from: https://www.ncbi.nlm.nih.gov/books/NBK220049/. Accessed December 22, 2020.

5. Metcalf CJ, Andreasen V, Bjørnstad ON, et al. Seven challenges in modeling vaccine preventable diseases. Epidemics. 2015;10:11-15. doi:10.1016/j.epidem.2014.08.004

6. Ophori EA, Tula MY, Azih AV, et al. Current trends of immunization in Nigeria: prospect and challenges. Trop Med Health. 2014;42 (2):67-75. doi:10.2149/tmh.2013-13

7. Onyeka IN, Ilika AL, Ilika FN, et al. Experiences from polio supplementary immunization activities in Anambra State, Nigeria. Niger $J$ Clin Pract. 2014;17(6):808-813. doi:10.4103/1119-3077.144406

8. Lee E, Lewis R, Makumbi I, et al. Haemophilus influenzae type b conjugate vaccine is highly effective in the Ugandan routine immunization program: a case-control study. Trop Med Int Health. 2008;13 (4):495-502. doi:10.1111/j.1365-3156.2008.02027.x

9. Lehmann D, Vail J, Firth MJ, et al. Benefits of routine immunizations on childhood survival in Tari, Southern Highlands Province, Papua New Guinea. Int J Epidemiol. 2004;34(1):138-148. doi:10.1093/ije/ dyh262

10. World Health Organization Global immunization vision and strategy 2006-2015. Geneva: World Health Organisation/UN Children's Fund; 2005. Available from: http://apps.who.int/iris/bitstream/ 10665/69146/1/WHO IVB 05.05.pdf. Accessed July 17, 2020.

11. World Health Organization/United Nations Children's Fund. State of the world's vaccines and immunization; 1996. Available from: whqlib doc.who.int/hq/1996/WHO_GPV_96.04.pdf. Accessed August 26, 2020.

12. National Primary Health Care Development Agency. Nigerian national routine immunization strategic plan (2013-2015). Abuja: National Primary Health Care Development Agency; 2013. Available from: https:/www.jhsph.edu/research/centers-and-insti tutes/ivac/resources/Nigeria-NRISP-Technical-Policy.pdf. Accessed September. 14, 2017.

13. WHO. Summary of WHO position papers: recommended routine immunizations for children. WHO Webpage; April 2019. Available from: https://www.who.int/immunization/policy/Immunization_rou tine_table2.pdf?ua=1. Accessed July 28, 2020.
14. WHO (African Region: Nigeria). WHO's contribution to immunization in Nigeria - October 2005 report. Abuja: World Health Organization.

15. National Primary Health Care Development Agency. National immunization policy 2009. Abuja; NPHCDA; 2009.

16. PAN Advisory Committee on Immunisation. Paediatric Association of Nigeria (PAN) recommended routine immunization schedule for Nigerian children. Niger J Paed. 2012;39:152-158. doi:10.4314/njp.v39i4.1

17. National Population Commission and ICF. Nigeria Demographic and Health Survey 2018 Key Indicators Report. Abuja, Nigeria, and Rockville, Maryland, USA: NPC and ICF; 2019.

18. Nasir UN, Bandyopadhyay AS, Montagnani F, et al. Polio elimination in Nigeria: a review. Hum Vaccin Immunother. 2016;12(3):658663. doi:10.1080/21645515.2015.1088617

19. Oli AN, Agu RU, Oli UC, et al. Safety evaluation in mice of the childhood immunization vaccines from two south-eastern states of Nigeria. Asian Pac J Trop Biomed. 2015;5(2):132-137. doi:10.1016/ S2221-1691(15)30157-X

20. Oli AN, Oli UC, Ejiofor OS, et al. An assessment, in mice, of the safety of the childhood immunization vaccines sourced from three south-eastern states of Nigeria. Trials Vaccinol. 2016;5:8-14. doi:10.1016/j.trivac.2015.10.001

21. Oli AN, Agu RU, Ihekwereme CP, et al. An evaluation of the cold chain technology in South-East, Nigeria using Immunogenicity study on the measles vaccines. Pan Afr Med J. 2017;27(Suppl 3):28. doi:10.11604/pamj.supp.2017.27.3.11491

22. United Nations Human Settlements Programme. Executive summary of structure plans for Awka, Onitsha and Nnewi and environs 20092027. UNHABITAT; 2009

23. FMOH. Guidelines for young persons' participation in research and access to sexual and reproductive health services in Nigeria. Abuja: FMOH; 2014. Available from: https:/www.popcouncil.org/uploads/pdfs/2014HIV YoungPersonsSRH-Nigeria.pdf. Accessed November 15, 2020.

24. NHREC. Policy statement regarding enrollment of children in research in Nigeria. Version 1.0. 6 October, 2016. Available from http://nhrec.net/policy-statement-regarding-enrollment-of-childrenin-research-in-nigeria/. Accessed November. 16, 2020.

25. Peretti D, Bastide A, Radford $H$, et al. RBM3 mediates structural plasticity and protective effects of cooling in neurodegeneration. Nature. 2015;518(7538):236-239. doi:10.1038/ nature 14142

26. Óskarssona Y, Guðnasona P, Jónsdóttir GA, et al. Public opinion on childhood immunisations in Iceland. Vaccine. 2015;33(51):72117216. doi:10.1016/j.vaccine.2015.10.125

27. GAVI, the vaccine alliance. Saving children's lives and protecting people's health by increasing equitable use of vaccines in lowerincome countries. September 2019. Available from: https://www. gavi.org/sites/default/files/document/2019/ImmunisationandSDGS. pdf. Accessed July 8, 2020.

28. Enwonwu KG, Ilika A, Ifeadike C, et al. Perception of childhood immunization among mothers of under-five children in Onitsha, Anambra State. Afrimedic J. 2018;6:59-64.

29. Jheetaa M, Newell J. Childhood vaccination in Africa and Asia: the effects of parents' knowledge and attitudes. Bull World Health Organ. 2008;2008(6):419. doi:10.2471/BLT.07.047159

30. Bangura JB, Xiao S, Qiu D, et al. Barriers to childhood immunization in sub-Saharan Africa: a systematic review. BMC Public Health. 2020;20(1):1108. doi:10.1186/s12889-020-09169-4

31. Raji MO, Sani AA, Ibrahim LS, et al. Assessment of the knowledge of fathers, uptake of routine immunization, and its associated factors in a rural community of North West Nigeria. Ann Afr Med. 2019;18 (2):97-102. doi:10.4103/aam.aam_41_18

32. Olugbenga-Bello A, Jimoh A, Oke O, et al. Maternal characteristics and immunization status of children in North Central of Nigeria. Pan Afr Med J. 2017;26:159. doi:10.11604/pamj.20 17.26.159.11530 
33. Jegede AS. What led to the Nigerian boycott of the polio vaccination campaign? PLoS Med. 2007;4(3):e73. doi:10.1371/journal.pmed.0040073

34. Oku A, Oyo-Ita A, Glenton C, et al. Factors affecting the implementation of childhood vaccination communication strategies in Nigeria: a qualitative study. BMC Public Health. 2017;17(1):200. doi:10.1186/ s12889-017-4020-6

35. McNeil DA, Mueller M, MacDonald S, et al. Maternal perceptions of childhood vaccination: explanations of reasons for and against vaccination. BMC Public Health. 2019;19(1):49. doi:10.1186/s12889-0186338-0
36. Adedokun $\mathrm{S}$, Uthman $\mathrm{O}$, Adekanmbi $\mathrm{V}$, et al. Incomplete childhood immunization in Nigeria: a multilevel analysis of individual and contextual factors. BMC Public Health. 2017;17(1):236. doi:10.1186/s12889-017-4137-7

\section{Publish your work in this journal}

The Journal of Multidisciplinary Healthcare is an international, peerreviewed open-access journal that aims to represent and publish research in healthcare areas delivered by practitioners of different disciplines. This includes studies and reviews conducted by multidisciplinary teams as well as research which evaluates the results or conduct of such teams or healthcare processes in general. The journal covers a very wide range of areas and welcomes submissions from practitioners at all levels, from all over the world. The manuscript management system is completely online and includes a very quick and fair peer-review system. Visit http://www.dovepress.com/testimonials. php to read real quotes from published authors. 